\title{
Implementation of Inquiry Based Electrical and Electronic Instructional Module in Vocational School
}

\author{
Letty Aryanti*, Nizwardi Jalinus², Asmar Yulastri ${ }^{3}$ iD \\ ${ }^{1,2,3}$ Department of Engineering, Padang State University, Sumatera Barat, Indonesia \\ *Corresponding author: lettyaryanti@gmail.com
}

\begin{abstract}
The importance of modules in learning as enhancing student learning outcomes. Thus, it is necessary to conduct a needs analysis for the development of inquiry-based modules in improving student learning outcomes.Thus, through this module students are taught to study independently and think critically. This study aims to conduct a needs analysis of the implementation of inquiry-based learning modules in basic subjects of electricity and electronics. This type of research is a qualitative descriptive study. The respondents chosen in this study were subject teachers and tenth grade students of Audio Video Engineering in Vocational Schools in Padang, which were 70 students and randomly selected. The instrument used in this study was an observation sheet in the form of a questionnaire (yes-no Question). The results of the study shows that students need inquiry-based modules more than books or other independent teaching materials in which $100 \%$ of students answered needing independent teaching materials and $80 \%$ of students answered needing modules.
\end{abstract}

Keywords: Modules, Inquiry, Basic Electricity And Electronics

$\begin{array}{ll}\text { History: } & \\ \text { Received } & : \text { 25 June } 2020 \\ \text { Revised } & : \text { 13 August } 2020 \\ \text { Accepted } & : 27 \text { September } 2020 \\ \text { Published } & : \text { 7 October } 2020\end{array}$

\section{Introduction}

Learning is a process and a very important element fundamental in the implementation of types and levels of education. Intruction and learning are one unit. Learning is a process of discovering and constructing meaning from information and experience, then the information is processed through students' perceptions, thoughts, and feelings (Reigeluth et al. 2017). Learning occurs when students combine new information and concepts into their memories so as to give birth to new abilities or skills (Dick Walter; Carey Lou; O Carey James., 2015). $21^{\text {st }}$ century learning does not only emphasize on student centered, but also more than that. $21^{\text {st }}$ century learning also emphasizes scientific learning so that students are able to think critically. $21^{\text {st }}$ century learning is characterized by information, computing, automation and communication. It means that learning is directed to increase student curiosity through the process of asking questions and not just answering questions (Sani, 2014). Through the process of asking questions, learning requires students to be active in the class, assisted by appropriate learning designs. Using scientific learning is one of recommended learning designs in $21^{\text {st }}$ century learning. Scientific learning generally involves students to do observations. Observation activities to obtain information are carried out through experiment activities, which can be replaced by evaluating information from various sources (Sani, 2014). 
Students, teachers, teaching materials and learning environment are important elements in learning process. If the objectives of learning are not fulfilled, then these elements must be rebuilt to become an effective system so that they can influence learning outcomes (Dick Walter et al. 2015). The errands of teacher in $21^{\text {st }}$ century learning are the facilitator, motivator and resource person (M.Bakhrun. 2018). Teacher must be able to convey the subject matter in a simple and understandable way and also can help students to work and solve problems.

Learning in $21^{\text {st }}$ century in Indonesia carried out by implementing scientific learning. One of teaching materials that can be used to guide and help students in learning is learning module. Modules are materials that are arranged into a form of unity that can be used to help students in the interests of learning (Rusman. 2011). Modules are learning resources in the form of printed media that are designed with simple language, thus modules can help students to learn independently. Therefore, through the module, students can carry out learning activities outside the classroom without being accompanied by a teacher. Modules are arranged in a language that is easy to be understood and is instructional so students need modules to help them achieve their learning goals (Arantika et al. 2018).

Modules are used to improve the learning effectiveness and efficiency at school because module is a part of an individual learning system and can help students to learn to the level of completion so as to activate learning activities through reading activities. But, not all developed modules can help students to be active and have a critical thinking character. In addition,, the other factors that can influence the learning process are using appropriate learning models that instill students' thinking skills and improve students' learning outcomes.

The standard process of core activities in the learning process must use a learning model, and learning resources must be adapted to the characteristics of students and subjects (M.Bakhrun, 2018). In basic subjects of electricity and electronics, students are required to do not only know but also must understand the subject matter, because the basic subjects of electricity and electronics are basic subjects for students to make electronic circuits and perform in other fields of Electronics. One of recommended learning models to be use is inquiry-based learning.

Inquiry theory in learning acts as a theoretical basis for social constructivism, which considers students as agents who must actively build knowledge through understanding and making meaning in their own way (Chu Samuel et al. 2017). It means that students must be able to think critically and have an inquiry mindset in learning. Inquiry learning helps students develop new knowledge and meaning through their involvement in formulating questions for checking purposes (Sani, 2014). Checking what is meant in inquiry learning is the process of gathering information, one of which is in the form of practical activities.

Main purpose of learning by inquiry method is to help students through questions compiled by the teacher and students get answers to their curiosity through the process of finding out, so that students' intellectual and thinking abilities can develop. In inquiry learning, teacher has an important role to guide students in conducting the investigation process. The guidance is carried out because in general, students do not have experience in inquiry learning, so learning must be structured structured by the teacher (Khoirul. 2017). While the development of inquiry-based learning modules is needed because it is effective in increasing the understanding of concepts and student learning outcomes (Wardani et al. 2016; Ikhsan \& Prayitno, 2016). Besides the use of inquiry-based modules in the classroom can improve student's cognitive learning outcomes (Risman \& Santoso, 2019; Ural, 2016; Vlassi \& Karaliota, 2013) and increase student activity in the classroom (Sipangkar et al 2018).

Based on observations and analysis that have been done in 3 vocational schools in Padang, 70 students are given questionnaires. It shows that in learning, students often miscommunicate learning materials and are passive in learning process because of the 
abstract nature of the delivered material. Besides, teaching materials that were used by students also do not fully assist students in solving problems. Students state that teaching materials used today have many shortcomings such as has not been helpful in the learning process because the modules are used only as reading material and have not reached the stage where learners are asked to solve problems through a certain approach. This kind of learning is not appropriate with the learning material in curriculum 2013 where subject matter is distinguished based on facts, concepts, principles and procedures. In addition, teaching materials used in learning process are still dominated to achieve knowledge, not including student activeness, scientific and critical thinking skills that were launched in curriculum 2013. So as to influence learning outcomes for the better, the presentation of material and learning steps must be changed (Koyama. 1993).

This research is in line with Lasmiyati (2014) entitled Development of Learning Modules to Improve Understanding of Junior High School Concepts and Interests. Similarity with this research is to discuss the development of modules in learning. The results of this study indicate that learning using modules is better and increase understanding of learning concepts, 8 out of 25 students compared to learning without using modules. The difference of research is in the research target, in which the previous research is located at SMPN 1 Pomalaa with the type of research development meanwhile in this study, the target is Vocational Schools in Padang and it used a qualitative descriptive study. It shows that the importance of modules in learning as enhancing student learning outcomes. Thus, it is necessary to conduct a needs analysis for the development of inquiry-based modules in improving student learning outcomes so that through this module students are taught to study independently and think critically.

\section{Materials and Methods}

This research is a qualitative descriptive study which was conducted at 3 vocational high schools in Padang. The subjects of the study were subject teachers and tenth grade audio video engineering students. This study describes facts or circumstances that appear to be related to learning. Qualitative descriptive research is all the symptoms or conditions that exist, that are symptoms according to what it is when the research was conducted (Nawawi \& Martini, 1996).

Population is a generalization area consisting of certain subjects established by researchers (Sugiyono, 2008). While the sample is a portion of the number and characteristics possessed by the population (Sugiyono, 2008). The population of this study were 3 vocational high schools in the city of Padang. Samples were randomly selected from tenth grade students.

Data were collected using questionnaires and interview sheets. The questionnaire was designed to determine the conditions of learning and learning resources used by students during learning. Interviews were conducted to confirm the results of the questionnaire that was answered. Some statements from the questionnaire were developed by the researchers themselves. The statement that is developed by the researcher is related to the application of process skills in teaching materials and types of teaching materials that are expected to help teachers train students' process skills. The questionnaire was divided into three groups of questions: students' opinions about the availability of teaching materials, students' opinions about the teaching materials used, and students' opinions about the expected independent teaching materials. 


\section{Results and Discussion}

\section{Student Activities in Learning Basic Electrical and Electronics Learning}

The results of the questionnaire which consists of 4 items by 70 respondents which is related to student activities in learning could be seen in Table 1.

Table 1. Student Activities in Learning Basic Electrical and Electronics Learning

\begin{tabular}{lcc}
\hline \multicolumn{1}{c}{ Question } & \multicolumn{2}{c}{ Answer (\%) } \\
\cline { 2 - 3 } & Yes & No \\
\hline $\begin{array}{l}\text { Students are motivated to ask questions } \\
\text { during the learning process }\end{array}$ & $27 \%$ & $73 \%$ \\
$\begin{array}{l}\text { Students learn to express their opinions } \\
\begin{array}{l}\text { Students work together in group } \\
\text { discussions }\end{array}\end{array}$ & $21 \%$ & $79 \%$ \\
$\begin{array}{l}\text { Students enjoy actively participating in the } \\
\text { learning process }\end{array}$ & $21 \%$ & $79 \%$ \\
\hline
\end{tabular}

From Table 1, it is known that more than $50 \%$ of 70 students in the class are passive when participated in learning. The students must get stimulus to be active in the learning process. To implement an active learning, the learning components must follow the challenges of the new learning approach, provide stimulus to students through feedback and support throughout the process (Tharayil et al. 2018). Scientific approach can be used to follow the new learning approaches that can improve student learning outcomes in the realm of cognitive, affective, and psychomotor (Hidayati. 2017; Deti Rostika, 2019). Scientific approaches in question include (1) the ability to create and design experiments; (2) the ability to conduct experiments and report results; (3) mastery of concepts in good scientific processes; and (4) the ability to present the results of experiments well. To make this approach works effectively, students need clear learning resources as a guidance for scientific-based learning. The learning resources can be used as a tool to smooth the course of teaching and learning activities, so that learning objectives work well. In another word, a learning process without right learning resources may not be carried out optimally.

\section{Student Opinions on the Availability of Learning Resources}

The results of the questionnaire that consists of 2 question items by 70 respondents which is describing the learning resources that are used by students as well as the limitations has felt by students while using existing learning resources could be seen in Table 2 .

Table 1. Student Opinions on the Availability of Learning Resources

\begin{tabular}{lcc}
\hline \multicolumn{1}{c}{ Question } & \multicolumn{2}{c}{ Answer (\%) } \\
\cline { 2 - 3 } & Yes & No \\
\hline $\begin{array}{l}\text { Do you use learning resources other than books } \\
\text { and job-sheets? }\end{array}$ & $100 \%$ & $0 \%$ \\
$\begin{array}{l}\text { Do you feel there are limitations to using learning } \\
\text { resources? For example, the completeness of the } \\
\text { material, format, technical explanation, design, } \\
\text { and color display }\end{array}$ & $72 \%$ & $28 \%$ \\
\hline
\end{tabular}

Based on Table 2, it can be seen that the sources used by students were in the form of books, job sheets, and internet based on teacher's instructions. But the source used is not scientific yet, and still in the form of ordinary reading material. Student needs a module as a leaning resource because the learning module will be easier to be used by students in applying the learning model. The learning module is not structured with monotonous 
activities, but equipped with various interesting learning activities and able to stimulate students to learn. Table 2 describes the transparency of modules used by students in learning. Modules that students have used cannot help students in reaching the learning goals. Whereas according to Wena (2009), modules are part of individual learning models that are used to assist students to achieve learning goals. Modules can be used as teaching material and can be a source of learning by students. Learning by using modules is an effective way to improve student learning outcomes (Yasin, 2014).

\section{Student Opinions on the Learning Resources Used}

Next is result of the questionnaire which consists of 5 question by 70 respondents that is about assessing the learning resources which have used by students. Obtained data about how have the learning resources trained students in conducting scientific learning could be seen in Table 3.

Table 2. Student Opinions on the Learning Resources Used

\begin{tabular}{|c|c|c|}
\hline \multirow{2}{*}{ Question } & \multicolumn{2}{|c|}{ Answer (\%) } \\
\hline & Yes & No \\
\hline $\begin{array}{l}\text { Are the learning resources used can train you to } \\
\text { observe and identify problems, events, or facts? }\end{array}$ & 0 & $100 \%$ \\
\hline $\begin{array}{l}\text { Can existing learning resources train you to collect } \\
\text { data? }\end{array}$ & $43 \%$ & $57 \%$ \\
\hline $\begin{array}{l}\text { Can the learning resources you use help you } \\
\text { analyze data/information? }\end{array}$ & 0 & $100 \%$ \\
\hline $\begin{array}{l}\text { Are the learning resources used to train you to plan } \\
\text { an experiment? }\end{array}$ & 0 & $100 \%$ \\
\hline $\begin{array}{l}\text { Does the use of existing learning resources train } \\
\text { you to prove hypotheses through experimentation } \\
\text { or theory? }\end{array}$ & 0 & $100 \%$ \\
\hline
\end{tabular}

Table 3 emphasizes how the ability of learning resources available in training students' skills, especially scientific skills. Learning takes place with the lecture method so that students receive more material from the teacher's explanation. Learning that tends to be centred on the teacher makes activities in analysing data and carrying out scientific activities in class rarely. When students work on assignments given by the teacher in learning, students collect data by using internet, or their respective notebooks. The use of learning resources such as textbooks and internet in learning process apparently does not fully help students in collecting data/information. It means that only a few students are able to retrieve information or data from the learning resources used. As well as learning resources used by students, do not train students to do scientific learning.

\section{Independent Learning Resources Needed by Students}

The results of the questionnaire which consists of 2 question items by 70 respondents that is describing the learning resources needed by students could be seen in Table 4.

Table 3. Independent Learning Resources Needed by Students

\begin{tabular}{lcc}
\hline \multicolumn{1}{c}{ Question } & \multicolumn{2}{c}{ Answer (\%) } \\
\cline { 2 - 3 } & Yes & No \\
\hline $\begin{array}{l}\text { Students need independent learning resources for } \\
\text { basic Electric and Electronics Subjects }\end{array}$ & $100 \%$ & 0 \\
Types of independent learning resources needed & &
\end{tabular}




\begin{tabular}{llcc}
\hline \multicolumn{1}{c}{ Question } & \multicolumn{2}{c}{ Answer (\%) } \\
\cline { 3 - 4 } & & Yes & No \\
\hline 1. & Text book & $21 \%$ & $79 \%$ \\
2. & LKS & 0 & $100 \%$ \\
3. & Modules & $80 \%$ & $20 \%$ \\
4. & Other teaching materials & $6 \%$ & $94 \%$ \\
\hline
\end{tabular}

Based on Table 4 which is about teaching materials needed by students, $100 \%$ of students answered needing independent teaching materials and $80 \%$ of students answering needing modules. This is relevant to the results of interviews with students in which students answer that they need modules as independent teaching materials that can be used to repeat material that is not understood well, besides students need modules more than books because modules are more concise meanwhile books has language that is not understable and complex material exposure. It is in line with the results of the study Arantika et al. (2018) which states that students need modules in learning more than books because less than $50 \%$ of students are able to understand books used during the learning process. In addition, research Rohmiyati, Ashadi, \& Utomo (2016) explains that the use of modules in learning is more effective than the use of worksheets. Modules can be used as teaching materials or media for effective learning. The use of modules in learning aims to make students can study independently with or without the teacher.

In addition to going through a questionnaire, to get students' analysis data, observations and interviews with the teacher are also carried out. This activity is carried out to determine the characteristics and environment of students. This analysis is carried out as a consideration for implementation of inquiry-based modules in basic subjects of electricity and electronics.

It is necessary for implementing inquiry-based learning modules. Besides being one of recommended learning models in curriculum 2013, an inquiry learning model is needed because the inquiry model is effective to improve student learning outcomes (Letty Aryanti et al. 2017), and also effective to improve student's mastery of concept (Praptiwi et al 2012). The essence of inquiry model is to involve students in a truly original research problem in the form of an investigation to help them for finding scientific problems. Learning scientific through an active process can shape scientific skill (Arthur A. Carin et al. 1997).

The inquiry learning model is one of the learning innovations that can direct students to make discoveries so that students can gain deeper knowledge. The learning model emphasizes how a person thinks and how it impacts on information processing. Inquiry that is applied in the learning process can improve students' ability to make observations and express answers to a problem through interpretation of data until a conclusion is reached. Thus, students need an inquiry-based learning module in the learning process to help student for having indipendent learning wherever and whenever. However, inquiry based learning module is going to help student to improve student's outcome and in line with some researches that have been done which state that the use of inquiry-based modules is effective to improve student learning outcomes (Rohmiyati et al., 2016; Wardani et al., 2016). In addition, inquiry-based learning module helps students to minimize misconceptions in learning (Setianingsih et al. 2018). Therefore, students have high interest in learning by using module in order to be able to read and re-understand material that is not understood well.

\section{Conclusion}

Teaching materials used by students in learning have not been maximized in helping students to improve students' science process skills, students' activeness and students' learning outcomes, the need for implementationof teaching materials in the form of modules 
because students need modules for independent learning. Module was chosen because it can facilitate students to learn, both learning together with educators or independently. Module is developed by using inquiry approach guidance.

\section{References}

Arantika, J., Saputro, S., \& Mulyani, S. (2018). Student's Need Analysis for the Development of Chemistry Modules Based Guided Inquiry to Improve Science Process Skill. IJPTE: International Journal of Pedagogy and Teacher Education, 2(January), 45. https://doi.org/10.20961/ijpte.v2i0.19750

Arthur A. Carin, R. B. S. (1997). Teaching Science through Discovery. Ohio: Merril Publishing Co.

Chu Samuel et al. (2017). 21st Century Skills Development Through Inquiry- Based Learning.

Deti Rostika, P. (2019). Pemahaman Guru Tentang Pendekatan Saintifik dan Implikasinya dalam Penerapan Pembelajaran di Sekolah Dasar. 11(1), 86-94.

Dick Walter; Carey Lou; O Carey James. (2015). The Systematic Design of Instruction. In Journal of Petrology. https://doi.org/10.1017/CBO9781107415324.004

Endryansyah., N. H. . (2014). Pengaruh Penggunaan Pendekatan Ilmiah (Scientific Approch) dalam Pembelajaran Terhadap Hasil Belajar Siswa Kelas XII TITL 1 SMK Negeri 7 Surabaya pada Standar Kompetensi Mengoperasikan Sistem Kendali Elektromagnetik. Jurnal Pendidikan Teknik Elektro, 2(2), 25-29.

Ikhsan, M., \& Prayitno, B. A. (2016). Pengembangan Modul Berbasis Inkuri Terbimbing Pada Materi Sistem Gerak Manusia Untuk Meningkatkan Hasil Belajar Siswa Kelas XI MIA SMA Negeri 1 Wera. 5(1), 133-142.

Khoirul Anam. (2017). Pembelajaran Berbasis Inkuiri: Metode dan Aplikasi. Yogyakarta: Pustaka Pelajar.

Koyama, M. (1993). Building A Two Axes Process Model Of Understanding Mathematics. Hiroshima Journal Of Mathemtics Education, 1, 63-73.

Lasmiyati, I. H. (2014). Pengembangan Modul Pembelajaran untuk Meningkatkan Pemahaman Konsep dan Minat SMP. PYTHAGORAS: Jurnal Pendidikan Matematika, 9, 161-174.

Letty Aryanti, Muhammad Anwar, Z. (2017). Pengaruh Penerapan Model Pembelajaran Inkuiri Terhadap Hasil Belajar Teknik Elektronika Dasar Siswa Kelas X SMKN 5 Padang. VOTEKNIKA, 5(2).

M.Bakhrun. (2018). Pelatihan dan Pendmapingan Implementasi Kurikulum 2013 SMK. Materi: Analisis Model Pembelajaran. Jakarta: Kemendikbud.

Praptiwi, L., Handayani, L., \& Artikel, I. (2012). Efektivitas Model Pembelajaran Eksperimen Inkuiri Terbimbing Berbantuan My Own Dictionary untuk Meningkatkan Penguasaan Konsep dan Unjuk Kerja Siswa SMP RSBI. Unnes Science Education Journal, 1(2).

Reigeluth, C. M., Beatty, B. J., \& Myers, R. D. (2017). Instructional-Design Theorist and Models: The Learner-Centered Paradigm Of Education, Volume IV. Newyork: Taylor and Francis. 
Risman, A., \& Santoso, S. (2019). Development of Guided Inquiry-Based Accounting Learning Module to Improve Students' Learning Outcomes in State Vocational High School 1 Karanganyar. International Journal of Multicultural and Multireligious Understanding, 6(2), 846. https://doi.org/10.18415/ijmmu.v6i2.946

Rohmiyati, N., Ashadi, A., \& Utomo, S. B. (2016). Pengembangan Modul Kimia Berbasis Inkuiri Terbimbing pada Materi Reaksi Oksidasi-Reduksi The Development of Chemical Modules Based Guided Inquiry in the Oxidation and Reduction Reactions Matter. Jurnal Inovasi Pendidikan IPA, 2(2), 223-229.

Rusman. (2011). Model-model Pembelajaran: Mengembangkan Profesionalisme Guru. Jakarta: PT Rajagrafindo Persada.

Sani, R. A. (2014). Pembelajaran Saintifik untuk Implementasi Kurikulum 2013. Jakarta: Bumi Aksara.

Setianingsih, E., Sunarno, W., \& Sukarmin, S. (2018). Pengembangan Modul Pembelajaran Dinamika Gerak Berbasis Inkuiri Terbimbing Untuk Siswa Kelas X SMA/MA. INKUIRI: Jurnal Pendidikan IPA, 7(2), 220. https://doi.org/10.20961/inkuiri.v7i2.22978

Sipangkar, Yeni, Juliani, R dan Siregar, A. (2018). pengaruh model pembelajaran inkuiri terbimbing terhadap hasil belajar dan aktivitas siswa. Jurnal Pendidikan Fisika, 7(2), 103-109.

Sugiyono. (2008). Metode Penelitian Kuantitatif. Bandung: Alfabeta.

Tharayil, S., Borrego, M., Prince, M., Nguyen, K. A., Shekhar, P., Finelli, C. J., \& Waters, C. (2018). Strategies to mitigate student resistance to active learning. International Journal of STEM Education, 5(1). https://doi.org/10.1186/s40594-018-0102-y

Ural, E. (2016). The Effect of Guided-Inquiry Laboratory Experiments on Science Education Students' Chemistry Laboratory Attitudes, Anxiety and Achievement. Journal of Education and Training Studies, 4(4), 217-227. https://doi.org/10.11114/jets.v4i4.1395

Vlassi, M., \& Karaliota, A. (2013). The Comparison between Guided Inquiry and Traditional Teaching Method. A Case Study for the Teaching of the Structure of Matter to 8th Grade Greek Students. Procedia - Social and Behavioral Sciences, 93, 494-497. https://doi.org/10.1016/j.sbspro.2013.09.226

Wardani, S., Nurhayati, S., \& Safitri, A. (2016). The Effectiveness of the Guided Inquiry Learning Module towards Students. International Journal of Science and Research (IJSR), 5(6), 1589-1594. https://doi.org/10.21275/v5i6.nov164512

Wena, M. (2009). Strategi Pembelajaran Inovatif Kontenporer: Suatu Tinjauan Konseptual Operasional. Jakarta: Bumiaksara.

Yasin, M. (2014). Pengembangan Modul Transmisi Otomatis Mobil untuk Meningkan Kualitas Hasil Belajar Siswa Kelas XI di Sekolah Menengah Kejuruan. Jurnal Pendidikan, 3, 1-9. 